\title{
Lung distribution, quantification, co-localization and speciation of silver nanoparticles after lung exposure in mice
}

\author{
Stijn Smulders ${ }^{\mathrm{a}, 1}$, Camille Larue ${ }^{\mathrm{b}, 1}$, Geraldine Sarret ${ }^{\mathrm{b}}$, Hiram Castillo-Michel ${ }^{\mathrm{c}}$, \\ Jeroen Vanoirbeek ${ }^{\mathrm{a}}$, Peter H.M. Hoet ${ }^{\mathrm{a}, *}$ \\ a Center for Environment and Health, KU Leuven, Leuven, Belgium \\ b ISTerre, Université Grenoble Alpes, CNRS, F-38041 Grenoble, France \\ ${ }^{\mathrm{c}}$ European Radiation Synchrotron Facility, Grenoble, France
}

\section{H I G H L I G H T S}

- Local Ag distribution, and co-localization with $\mathrm{Fe}, \mathrm{Cu}$ and $\mathrm{S}$, was determined.

- XRF, $\mu$ XANES, and $\mu$ PIXE techniques were used.

- A quarter of all macrophages in the lumen of the airways contained ENPs.

- A large part of the ENPs was dissolved and complexed to thiol-containing molecules.

- Ag, S-rich spots were enriched in Fe and $\mathrm{Cu}$, suggestive for metallothioneins (MTs).

\section{A R T I C L E I N F O}

\section{Article history:}

Received 14 May 2015

Received in revised form 30 June 2015

Accepted 2 July 2015

Available online 7 July 2015

\section{Keywords:}

Nanoparticles

Silver

Micro X-ray fluorescence ( $\mu$ XRF)

Micro X-ray absorption near edge structure spectroscopy ( $\mu$ XANES)

Micro proton-induced X-ray emission ( $\mu$ PIXE)
G R A P H I C A L A B S T R A C T
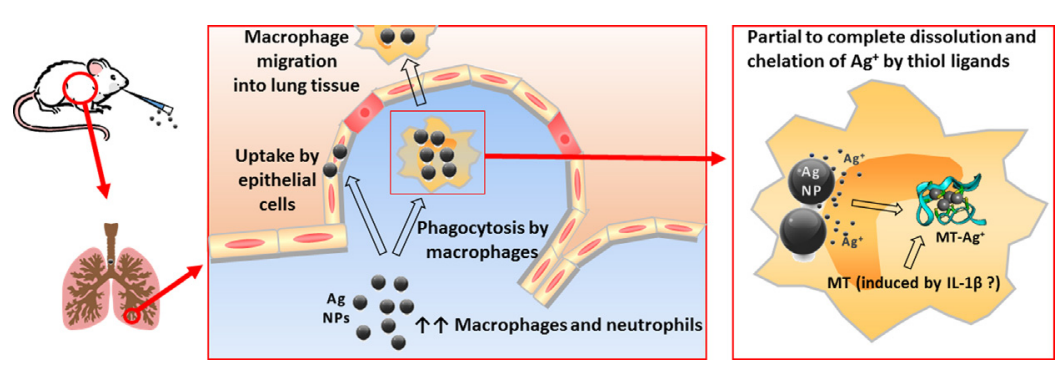

\begin{abstract}
A B S T R A C T
Large knowledge gaps still exist on the toxicological mechanisms of silver (Ag) engineered nanoparticles (ENPs); a comprehensive understanding of the sources, biodistribution, toxicity and transformation of Ag ENPs along their life cycle and after transfer in living organisms is needed. In a previous study, mice were pulmonary exposed to Ag ENPs and local (lung) and systemic toxic effects together with biodistribution to organs including heart, liver, spleen and kidney were investigated. Here, $\mathrm{Ag}$ lung distribution, local concentration, co-localization with other elements such as Fe, $\mathrm{Cu}$ and $\mathrm{S}$, and speciation were determined after lung exposure to Ag ENPs using micro X-ray fluorescence ( $\mu \mathrm{XRF}$ ), micro X-ray absorption near edge structure spectroscopy ( $\mu$ XANES) and micro proton-induced X-ray emission ( $\mu$ PIXE) techniques. We found that approximately a quarter of all macrophages in the lumen of the airways contained ENPs. High local concentrations of Ag were also detected in the lung tissue, probably phagocytized by macrophages. The largest part of the ENPs was dissolved and complexed to thiol-containing molecules. Increased concentrations of $\mathrm{Fe}$ and $\mathrm{Cu}$ observed in the Ag-rich spots suggest that these molecules are metallothioneins (MTs). These results give more insights on the behavior of Ag ENPs in the lung in vivo and will help in the understanding of the toxicological mechanisms of Ag ENPs.
\end{abstract}

(C) 2015 Elsevier Ireland Ltd. All rights reserved.

\footnotetext{
* Corresponding author at: Department of Public Health and Primary Care Center for Environment and Health, Herestraat 49 mailbox 706 , B-3000 Leuven, Belgium. E-mail addresses: stijn.smulders@med.kuleuven.be (S. Smulders), camille.Larue@ruhr-uni-bochum.de (C. Larue), geraldine.sarret@ujf-grenoble.fr (G. Sarret), hiram.castillo-michel@esrf.fr (H. Castillo-Michel), jeroen.vanoirbeek@med.kuleuven.be (J. Vanoirbeek), peter.hoet@med.kuleuven.be (P.H.M. Hoet).

1 These authors contributed equally to this manuscript.
} 


\section{Introduction}

Due to their antimicrobial properties, silver (Ag) engineered nanoparticles (ENPs) are one of the most widely used ENPs with applications in paints and coatings, cosmetics, electronics, water disinfection, food packaging and textiles (Hanus and Harris, 2013; Som et al., 2011; Li et al., 2008). Furthermore, Ag ENPs can be found in biomedical applications including prostheses, wound dressings and surgical instruments (Chen and Schluesener, 2008; Ahamed et al., 2010).

The growing use of Ag ENPs in commercial products will inevitably lead to increased exposure to $\mathrm{Ag}$ in the environment and the general population (Larue et al., 2014). To predict the risk on human health, a comprehensive understanding of the source, biodistribution, toxicity and transformation of Ag ENPs along their life cycle and after transfer into living organisms is needed. The debate is going on about the source of Ag ENP toxicity and it remains unclear to what extent Ag ENPs or the released Ag ions are responsible for the toxic effects (Yu et al., 2013). In particular, Ag ions released from the ENPs were shown to interact with vital enzymes and proteins, affecting cellular respiration and ion transport, finally resulting in the death of bacteria, viruses and fungi (Levard et al., 2012).

Several studies have been conducted investigating the dissolution of $\mathrm{Ag}$ ENPs in artificial body fluids such as fluids representing the environment of the stomach, blood and airways (Stebounova et al., 2011a; Leo et al., 2013). Leo et al. (2013) studied the effect of a model pulmonary surfactant on Ag ENPs, and showed a decrease in the kinetics of Ag ENP dissolution and of their aggregation. Although there are published data on $\mathrm{Ag}$ localization and speciation in plants exposed to Ag ENPs (Larue et al., 2014), equivalent data on animal cells and tissues after Ag ENP exposure is lacking. Both in vitro and in vivo toxicity of Ag ENPs has already been studied; toxic effects such as glutathione depletion, mitochondrial deviations and damage to cell membranes were observed in vitro (Wijnhoven et al., 2009). Long-term or high-dose exposure to Ag ENPs in vivo leads to inflammation, small granulomatous lesions and changes in lung function (Sung et al., 2008; Sung et al., 2009; Stebounova et al., 2011b).

In a previous study, we evaluated the local (lung) and systemic toxic effects along with biodistribution to organs including heart, liver, spleen and kidney after lung exposure to Ag ENPs in mice (Smulders et al., 2014). We observed some toxic effects as seen by an increased neutrophil count and a 2-fold increase in the proinflammatory cytokines keratinocyte chemoattractant (KC) and interleukin-1ß (IL-1ß) in the lung tissue, with no systemic toxicity. Moreover, extrapulmonary distribution of Ag to the liver, spleen and kidney was seen. In this study, mice were exposed to Ag ENPs by oropharyngeal aspiration. Ag lung distribution, local concentration, co-localization with other elements such as $\mathrm{Fe}, \mathrm{Cu}$ and $\mathrm{S}$, and speciation were determined using several techniques including micro X-ray fluorescence ( $\mu \mathrm{XRF}$ ), micro proton-induced X-ray emission ( $\mu$ PIXE), Rutherford backscattering spectroscopy (RBS) and micro X-ray absorption near edge structure ( $\mu$ XANES) spectroscopy. This study gives more insights on the behavior of Ag ENPs in the lung in vivo and will help in the understanding of the toxicological mechanisms of Ag ENPs.

\section{Materials and Methods}

\subsection{Materials}

Ag ENPs were provided by industrial project partners involved in the European FP7 project Nanohouse. The same Ag ENPs were already used in nanotoxicological studies (Smulders et al., 2014;
Kaiser et al., 2013), ecotoxicological studies (Larue et al., 2014) and a study assessing the release of Ag ENPs from nano-containing paints (Zuin et al., 2013). Isoflurane (Forene ${ }^{\circledR}$ ) was obtained from Abbott Laboratories (S.A. Abbott N.V., Ottignies, Belgium) and pentobarbital (Nembutal ${ }^{\circledR}$ ) from Sanofi Santé Animale (CEVA, Brussels, Belgium).

\subsection{Particle characterization}

Dynamic light scatteringand zeta potential measurement were performed with a nanozS instrument (Malvern). Ag ENPs were suspended in saline $(0.9 \% \mathrm{NaCl})$ at a concentration of $0.8 \mathrm{mg} / \mathrm{ml}$.

\subsection{Mice}

Male BALB/c OlaHsd mice (6 week old) were obtained from Harlan (Horst, The Netherlands). The mice were kept in a conventional animal house with 12 -h dark/light cycles. They were housed in filter top cages and received lightly acidified water and pelleted food (Trouw Nutrition, Ghent, Belgium) ad libitum. All experimental procedures were approved by the local Ethical Committee for Animal Experiments.

\subsection{Experimental protocol}

On days $0,7,14,21$ and 28, mice received under light isoflurane anesthesia an oropharyngeal aspiration $(25 \mu \mathrm{l})$ of Ag ENPs $(0.8 \mathrm{mg} / \mathrm{ml})$ or vehicle (saline $(0.9 \% \mathrm{NaCl}))$, this results in a total dose of $100 \mu \mathrm{g}$ per mouse $(4 \mathrm{mg} / \mathrm{kg}$ ). Mice were sacrificed by an intraperitoneal injection of pentobarbital ( $90 \mathrm{mg} / \mathrm{kg}$ body weight) 2 days after the last exposure (day 30) and an autopsy was performed.

\subsection{Bronchoalveolar lavage}

The lung was lavaged, in situ, three times with $0.7 \mathrm{ml}$ sterile saline $(0.9 \% \mathrm{NaCl})$, and the recovered fluid was pooled. The bronchoalveolar lavage (BAL) fluid was centrifuged $(1000 \mathrm{~g}$, $10 \mathrm{~min})$ and $250 \mu \mathrm{l}$ of the resuspended pellets (100,000 cells/ $\mathrm{ml}$ ) were spun (300 g, $6 \mathrm{~min}$ ) (Cytospin 3, Shandon, TechGen, Zellik, Belgium) onto microscope slides, air-dried and stained (Diff-Quik ${ }^{\circledR}$ method, Medical Diagnostics, Düdingen, Germany) for macrophage and neutrophil cell counts. After taking BAL fluid, the lungs were instilled with $4 \%$ formaldehyde until full inflation of all lobes, as judged visually, for further analyses.

\section{6. $\boldsymbol{\mu} \mathbf{X R F}$ and $\mu X A N E S$}

$\mu \mathrm{XRF}$ and $\mathrm{Ag} \mathrm{L}_{\mathrm{III}}$-edge $\mu$ XANES measurements were performed on the scanning X-ray microscope on ID21 beamline at the ESRF (European Synchrotron Radiation Facility, France) in cryo-conditions using a vibration-free cryo- stage, passively cooled by a liquid nitrogen dewar.

A small piece of the lung was flash-frozen in liquid nitrogen, embedded in OCT $^{\mathbb{R}}$ resin and then cut in thin sections $(20 \mu \mathrm{m})$ using a cryomicrotome and directly transferred to the cryo-stage. $\mu \mathrm{XRF}$ maps were recorded with various step sizes (from $0.3 \mu \mathrm{m} \mathrm{x}$ $0.3 \mu \mathrm{m}$ to $3 \mu \mathrm{m} \times 3 \mu \mathrm{m}$ ) with incident energy of $3.42 \mathrm{keV}$, and dwell time of $200 \mathrm{~ms}$. $\mu \mathrm{XRF}$ data were processed using PyMca software (Sole et al., 2007) as in (Larue et al., 2014). Ag $\mathrm{L}_{\mathrm{III}}$-edge $\mu$ XANES spectra were recorded in regions of interest of the maps (Ag-rich regions). $\mu$ XANES data processing and linear combination fitting were achieved with Athena software using reference compounds acquired previously (Larue et al., 2014). 


\section{7. $\boldsymbol{\mu P I X E}$ and RBS}

Distribution of endogenous elements (P, S, K, Fe and $\mathrm{Cu}$ ) and $\mathrm{Ag}$ was mapped by $\mu$ PIXE coupled to RBS recorded simultaneously on the AIFIRA nuclear microprobe (Applications Interdisciplinaires de Faisceaux d'Ions en Région Aquitaine, CENBG, France). A $2.5 \mathrm{MeV}$ proton beam was focused to $2.5 \mu \mathrm{m} \times 2.5 \mu \mathrm{m}$ with an average intensity of $1000 \mathrm{pA}$. Freeze-dried cross-sections cutted from the samples prepared during the synchrotron experiment were analyzed. Data were processed using SIMNRA (Mayer, 1999) and Gupix (Campbell et al., 2000) softwares.

\subsection{Statistical analysis}

Data in Table 1 are presented as mean and standard deviations (SD). All data were analyzed using the non-parametric KruskalWallis test followed by a Dunn's multiple comparison test (Graphpad Prism 4.01, Graphpad Software Inc., San Diego, USA). A level of $p<0.05$ was considered significant.

\section{Results}

Analysis of the ENPs by dynamic light scattering (DLS) showed a polydisperse suspensie with 3 populations: $130 \mathrm{~nm}(11 \%$ in number), $506 \mathrm{~nm}$ (89\% in number), and $5180 \mathrm{~nm}$ (0.1\% in number). The particles were negatively charged with a zeta potential of $-31 \mathrm{mV}$. Inductively coupled plasma optical emission spectroscopy (ICP-OES) measurements showed impurities of Ca $(216.8 \mu \mathrm{g} / \mathrm{g})$, $\mathrm{Fe}(23.8 \mu \mathrm{g} / \mathrm{g})$ and $\mathrm{Cu}(0.6 \mu \mathrm{g} / \mathrm{g})$. Transmission electron microscopy (TEM) analysis of Ag ENPs has been published before by (Smulders et al., 2012) and showed a heterogenous composition with spherical $(25 \mathrm{~nm})$ and rod-shaped $(80-90 \mathrm{~nm})$ ENPs (Fig. S1).

Increases in total cells $\left(88.7( \pm 14.6) \times 10^{3}\right.$ vs $\left.38.2( \pm 15.4) \times 10^{3}\right)$, macrophages $\left(75.8( \pm 17.4) \times 10^{3}\right.$ vs $\left.37.9( \pm 16.6) \times 10^{3}\right)$ and neutrophils $\left(12.9( \pm 10.4) \times 10^{3}\right.$ vs $\left.0.3( \pm 0.3) \times 10^{3}\right)$ in the BAL fluid were seen in Ag-exposed mice compared to control mice. In the Ag-exposed group 26\% of the BAL macrophages contained ENPs as judged visually using light microscopy (Fig. 1). Note that this visual examination detects large agglomerates or precipitates of $\mathrm{Ag}$ only. No incorporation of ENPs was observed in neutrophils of the BAL fluid.

The elemental distribution of $\mathrm{Ag}$ in the lung after lavage was studied by $\mu$ XRF on thin sections. No spots of Ag were observed in non-exposed control animals (Fig. S2). Lung slices of mice exposed to $\mathrm{Ag}$ ENPs showed clear round-shaped hot spots of Ag; magnification of the Ag-rich regions show spot sizes of around $5 \mu \mathrm{m}$ (Fig. 2 and Fig. S3). $\mathrm{L}_{\text {III- }}$-edge $\mu$ XANES spectra were recorded on three Ag-rich spots identified by $\mu$ XRF and Ag speciation was determined by linear combination fits (Fig. 3). In two spots, Ag was still partially present as elemental $\mathrm{Ag}$ (spot 2: $37 \%$, spot 3: $55 \%$ ). Spot 1 showed $100 \%$ oxidative dissolution and recomplexation of $\mathrm{Ag}^{+}$ions to thiol-containing molecules. These molecules may correspond to cysteine, glutathione and/or metallothionein (MT),

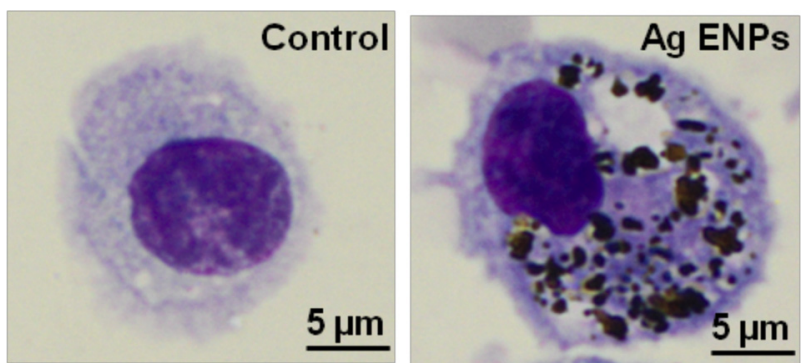

Fig. 1. Representative image of macrophage without and with Ag ENPs in its cytoplasm.

although XANES cannot distinguish among them. Spot 2 and 3 showed respectively $63 \%$ and $45 \%$ dissolution and recomplexation to the same type of ligands.

$\mu$ PIXE and RBS analyses were used to obtain local concentrations of Ag. Three out of eight analyzed regions (approximately $200 \mu \mathrm{m} \times 200 \mu \mathrm{m}$ ) in the lung tissue showed the presence of $\mathrm{Ag}$ spots with an average size of $5 \mu \mathrm{m}$. Two of these regions are shown in Fig. S4. The concentration of different elements in Ag-rich spots were determined and compared to concentrations in the whole lung section. Significant higher concentrations of $\mathrm{Cu}$, Fe and $\mathrm{S}$ were found in the $\mathrm{Ag}$-rich spots (Table 1 ). The $\mathrm{Cu} / \mathrm{Ag}, \mathrm{Fe} / \mathrm{Ag}$ and $\mathrm{S} / \mathrm{Ag}$ ratios were much higher than in the original NPs, so these elements did not come from the impurities detected in them.

\section{Discussion}

As for all ENPs, nano-Ag may enter the human body through inhalation, skin contact and ingestion (food, drinking water), and have the potential to pass the air-blood and even the blood-brain barrier (Yang et al., 2010). Inhalation of dust containing Ag ENPs occurs primarily in occupational settings including manufacturing and application of $\mathrm{Ag}$-containing products. Inhalation studies showed distribution of Ag to extrapulmonary organs including liver, kidney, spleen, brain and heart; however, these studies did not reveal whether $\mathrm{Ag}$ reached these organs as ions or ENPs (Sung et al., 2009; Takenaka et al., 2001; Ji et al., 2007). Ag ENP exposure can cause genotoxic effects and cellular damage through generation of oxidative stress, resulting in inflammation and apoptotic or necrotic death. These toxic effects strongly depend on the physico-chemical characteristics of the Ag ENPs.

In this study, we investigated the distribution, speciation, concentration and co-localization with other elements of Ag ENPs in the lungs of mice. We observed uptake of Ag ENPs by approximately a quarter of all macrophages in the lumen of the airways (BAL fluid), while no neutrophils containing ENPs were found. Furthermore, $\mathrm{Ag}$ was also found in the lung tissue; we assume that these Ag-rich spots represent macrophages filled with ENPs present in the lumen (not removed by lavage) and in the lung tissue. However, uptake by lung epithelial cells cannot be excluded.

Table 1

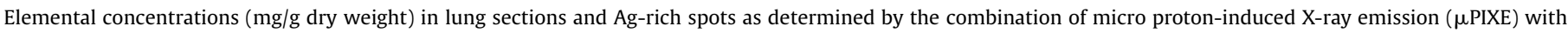

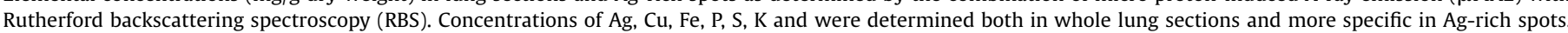

\begin{tabular}{|c|c|c|c|c|c|}
\hline Element & Whole lung section & $\begin{array}{l}\text { Mean } \\
\text { Ag-rich spots }\end{array}$ & Ag-rich spot 1 & Ag-rich spot 2 & Ag-rich spot 3 \\
\hline $\mathrm{Ag}$ & $0.2 \pm 0.3$ & $14.8 \pm 12.2^{*}$ & 27.9 & 13.0 & 3.6 \\
\hline $\mathrm{Cu}$ & $0.10 \pm 0.03$ & $0.23 \pm 0.04^{*}$ & 0.27 & 0.19 & 0.23 \\
\hline $\mathrm{Fe}$ & $0.97 \pm 0.07$ & $1.18 \pm 0.06^{*}$ & 1.12 & 1.22 & 1.19 \\
\hline $\mathrm{P}$ & $275 \pm 40$ & $355 \pm 27$ & 325 & 376 & 364 \\
\hline S & $204 \pm 40$ & $362 \pm 60^{*}$ & 365 & 421 & 302 \\
\hline K & $108 \pm 33$ & $142 \pm 41$ & 121 & 115 & 190 \\
\hline
\end{tabular}

$p<0.05$ compared to whole lung section. n.d.: not determined. 
a)
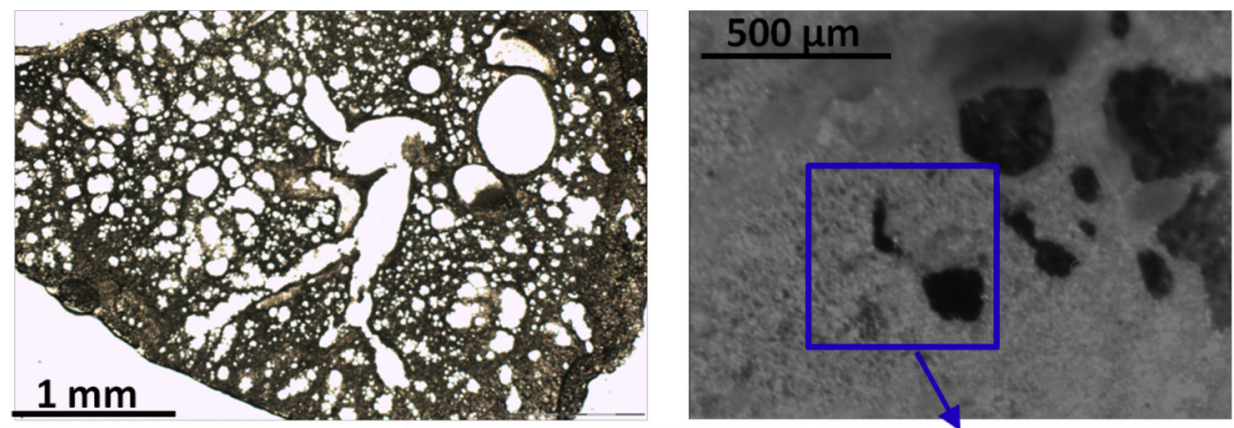

b)
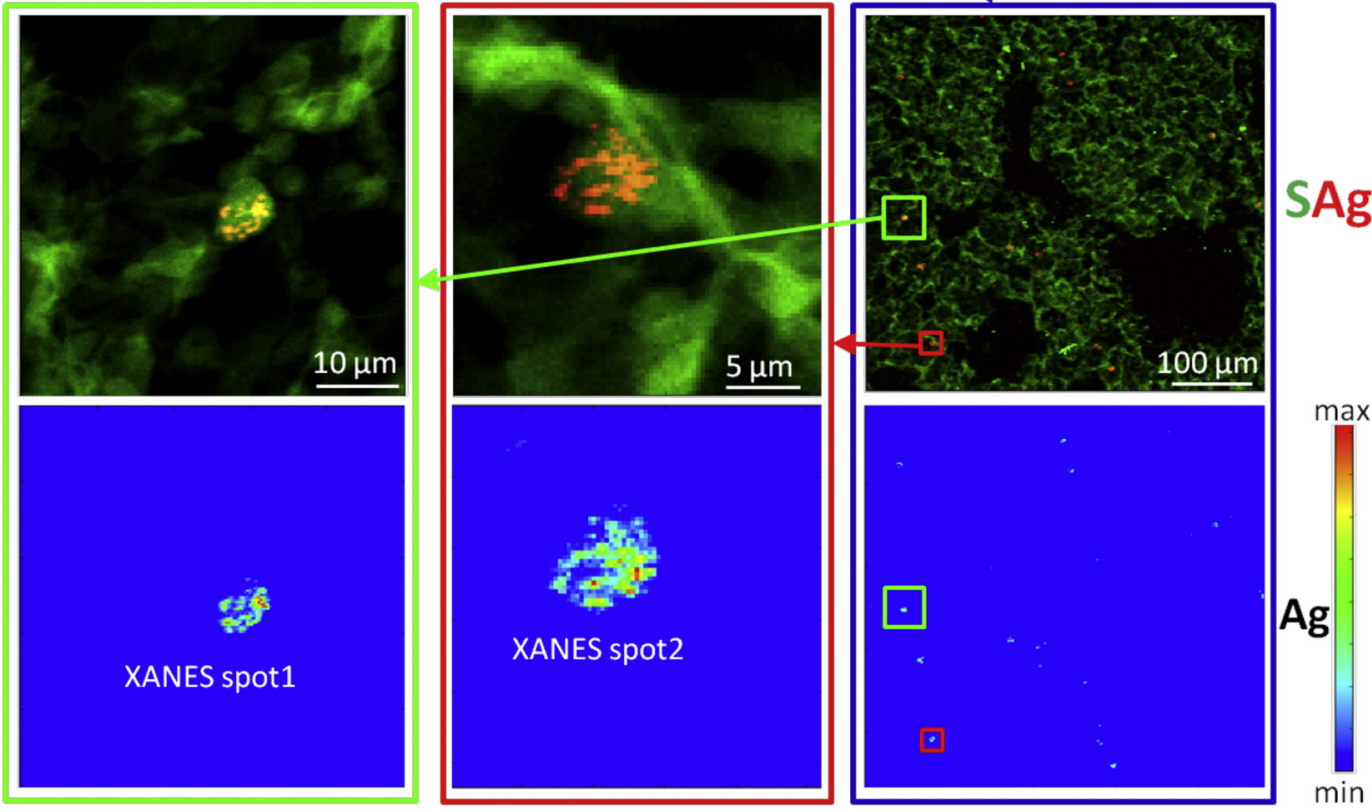

SAg
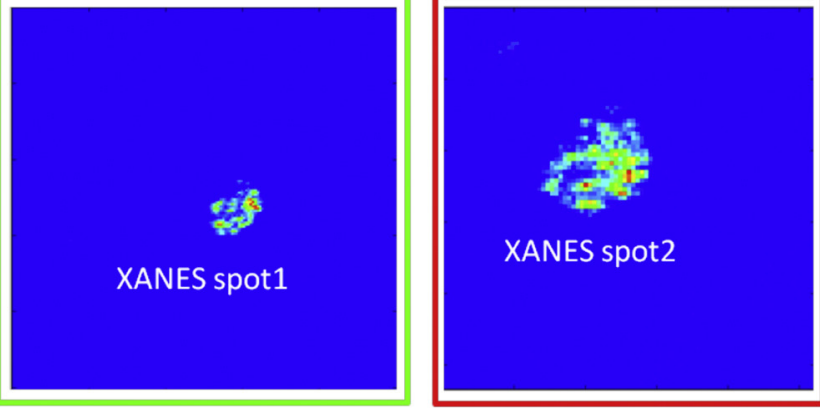

Fig. 2. Distribution of Ag in the lungs using micro X-ray fluorescence ( $\mu \mathrm{XRF}$ ).

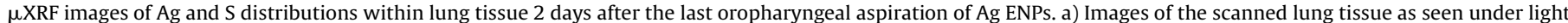

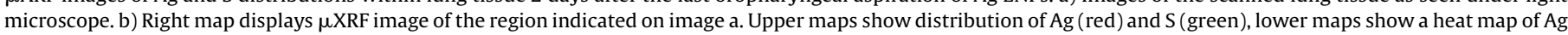
distribution. The left and middle maps represent magnifications of two spots indicated on the right map.

Other inhalation and instillation studies already showed that the largest part of the ENPs were phagocytized by alveolar macrophages and transported to the draining lymph nodes or removed by respiratory mucociliary clearance (Geiser and Kreyling, 2010). Once removed from the lungs, they can reach the stomach and gastrointestinal tract, can be taken up in the gut or will finally be excreted. Depending on the physicochemical properties of the particles (size, aggregation status, solubility, shape, ... ), a minor fraction of the particles that is not cleared from the lung or taken up by macrophages can translocate through the air-blood barrier into the circulation and will accumulate in secondary organs (Luyts et al., 2013). In a previous Ag ENP biodistribution study, we hypothesized that the Ag ENPs easily dissolve and ions cross the air-blood barrier (Smulders et al., 2014). Here, $\mu$ XANES analyses showed that the administered Ag ENPs were mostly present in macrophages, either partially or totally dissolved and chelated by thiol-containing ligands such as cysteine, glutathione or MT. The increased amount of S observed in these spots was consistent with the presence of thiol-containing molecules. The persistence of elemental Ag in macrophages suggests that some (if not all) Ag is taken up as ENP by these cells, and that dissolution and chelation occurs hereafter.

MTs are a family of cysteine-rich proteins that cooperate with glutathione in maintaining the cellular redox state (Nordberg and Arner, 2001). Localized in the cell cytoplasm and in some organelles including mitochondria and lysosomes, they play a role in a number of functions including (toxic) metal detoxification and protecting the cell against damage from reactive oxygen species (ROS) (Sutherland et al., 2010; Namdarghanbari et al., 2011). In natural conditions, the metal binding site consisting of 20 cysteine residues is occupied by $\mathrm{Zn}$ ions (Babula et al., 2012). However, these ions can be substituted for other metal ions such as $\mathrm{Ag}, \mathrm{Cu}, \mathrm{Cd}, \mathrm{Hg}, \mathrm{Pb}$ and $\mathrm{Fe}$ and protect cells against the toxicity of these metals. It is known that cysteine, and more generally thiol-containing molecules, are extremely strong binding ligands for $\mathrm{Ag}$ ions (Adams and Kramer, 1999; Liu et al., 2012).

It has been shown that expression of MTs is induced in inflammatory lung diseases (Inoue et al., 2008); Kaewamatawong et al. (2014) demonstrated the expression of MTs after lung exposure to colloidal Ag ENPs in mice. In a previous study, we showed the inflammatory effects of pulmonary administered $\mathrm{Ag}$ ENPs, the same ENPs as used in this study, with infiltration of neutrophils and expression of the pro-inflammatory cytokine IL-1 $\beta$ (Smulders et al., 2014), a known inducer of MT gene expression (De et al., 1990). In addition MT production can also be up regulated via MTF-1 binding to metal-response elements in the promoter regions of MT genes as shown in the presence of Ag-ions in Drosophila (Atanesyan et al., 2011) In this study, we demonstrated that the administered Ag ENPs are partially or completely dissolved with chelation of the released $\mathrm{Ag}$ ions by MTs or other thiol-containing molecules. Furthermore, higher 


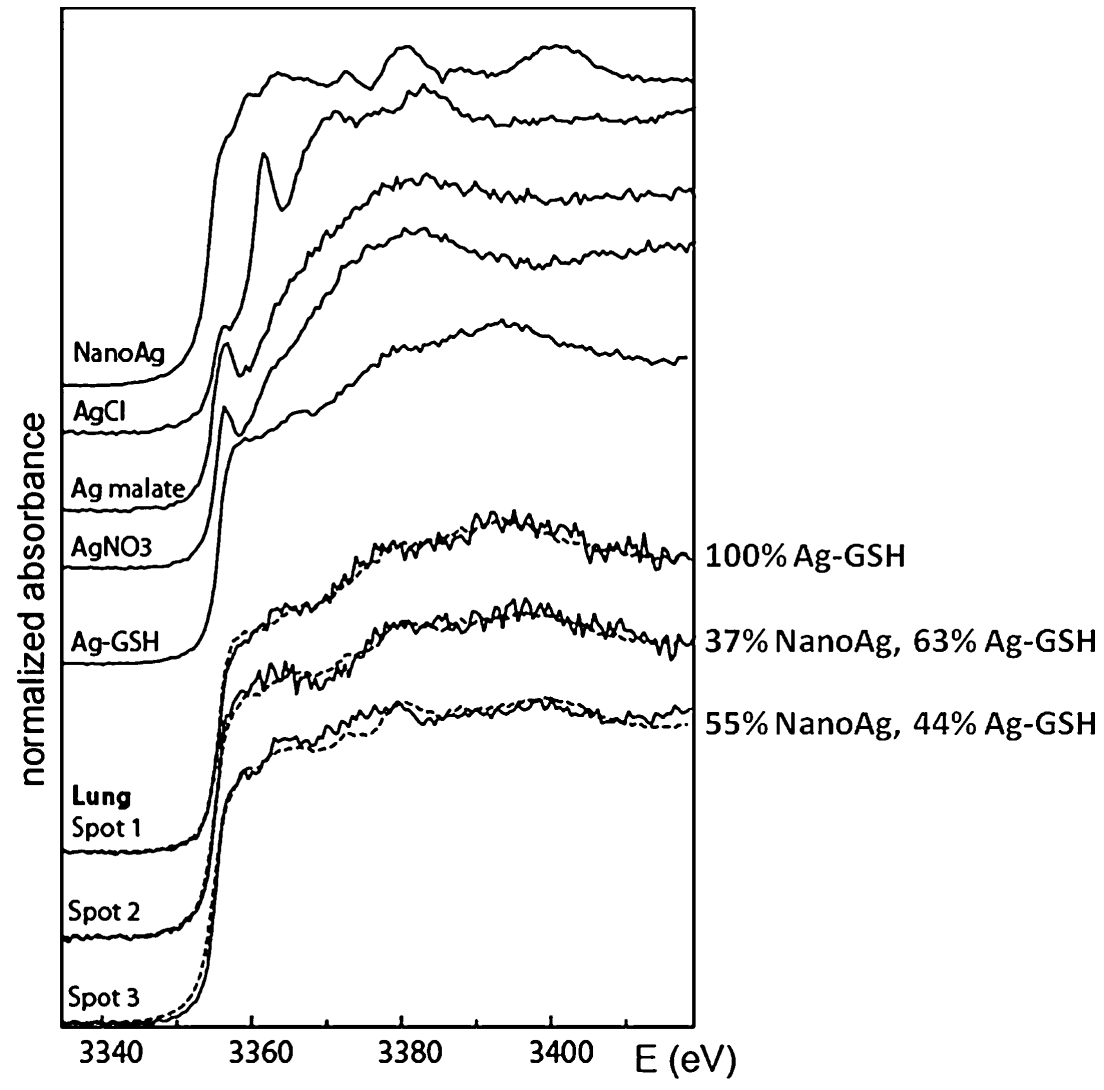

Fig. 3. Speciation by Ag $\mathrm{L}_{\mathrm{III}}$-edge micro X-ray absorption near edge structure ( $\mu$ XANES) spectroscopy.

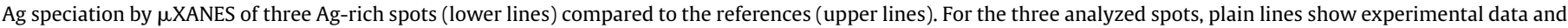
dotted lines represent the linear combination fit. Spot 1 and 2 correspond to the indicated spots in Fig. 2; spot 3 corresponds to the indicated spot in Fig. S2.

concentrations of the metals Fe and $\mathrm{Cu}$ were observed in the Agrich spots. Although the Ag ENPs contain impurities of $\mathrm{Fe}$ and $\mathrm{Cu}$, the concentration of these impurities is too low to fully explain the observed increase. As hypothesized before, we assume that higher amount of MTs are present in the Ag-rich spots, explaining the co-localization of other endogenous metals including $\mathrm{Fe}$ and $\mathrm{Cu}$.

\section{Conclusion}

In conclusion, we demonstrated that the administered Ag ENPs are taken up by macrophages and are partially to completely dissolved and recomplexed to thiol-containing molecules including MTs. A synthetic scheme in Fig. 4 gathers the present findings in combination with those obtained during our previous study. These results give more insights on the behavior of Ag ENPs in vivo and will help in the understanding of the toxicological mechanisms of Ag ENPs.

\section{Acknowledgements}

This work was supported by the Seventh Framework Program of the European Commission NanoHouse-Grant (Agreement No. 207816). We acknowledge the European Synchrotron Radiation Facility synchrotron for provision of beamtime (ID21 beamline).
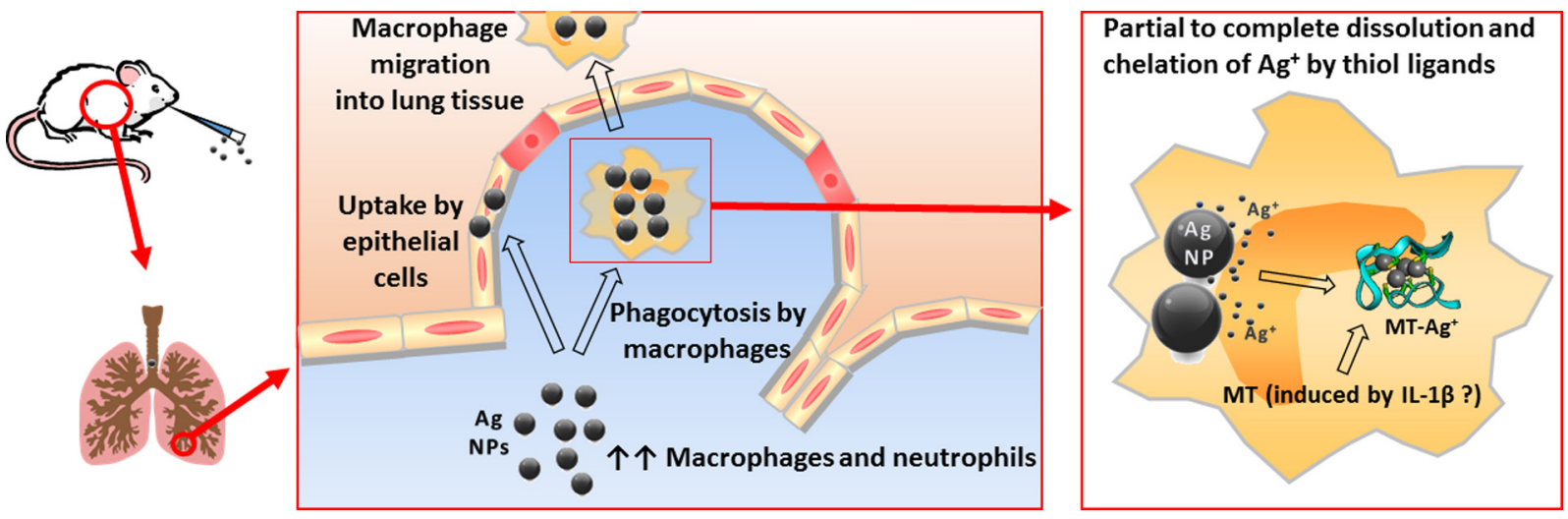

Fig. 4. Synthetic scheme of the potential pathways occurring in the lungs after Ag ENP exposure.

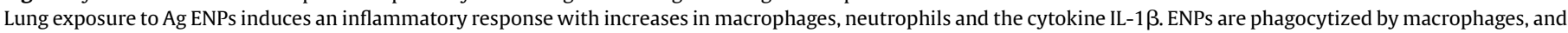

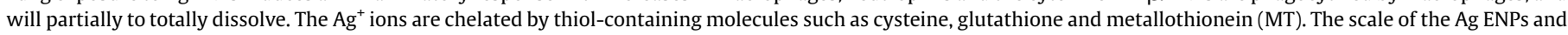
ions is not representative. 
The authors are grateful to AIFIRA for providing access to the nuclear microprobe. ISTerre is part of Labex OSUG@2020 (ANR10 LABX56) and Labex Serenade (ANR-11-LABX-0064). We also thank equipex NanoID (ANR-10-EQPX-39).

\section{Appendix A. Supplementary data}

Supplementary data associated with this article can be found, in the online version, at http://dx.doi.org/10.1016/j. toxlet.2015.07.001.

\section{References}

Adams, J.R., Kramer, N.W.H., 1999. Determination of silver speciation in wastewater and receiving waters by competitive ligand equilibration/solvent extraction. Environ. Toxicol. Chem. 18, 2674-2680.

Ahamed, M., Alsalhi, M.S., Siddiqui, M.K., 2010. Silver nanoparticle applications and human health. Clin. Chim. Acta 411, 1841-1848.

Atanesyan, L., Günther, V., Celniker, S.E., Georgiev, O., Schaffner, W., 2011. Characterization of MtnE, the fifth metallothionein member in Drosophila. J. Biol. Inorg. Chem. 16, 1047-1056.

Babula, P., Masarik, M., Adam, V., Eckschlager, T., Stiborova, M., Trnkova, L., Skutkova, H., Provaznik, I., Hubalek, J., Kizek, R., 2012. Mammalian metallothioneins: properties and functions. Metallomics 4, 739-750.

Campbell, T.L., Maxwell, J.A., Nejedly, Z., 2000. The Guelph PIXE software package III: alternative proton database. Nucl. Instrum. Methods Phys. Res. 170, 193-204.

Chen, H.J., Schluesener, X., 2008. Nanosilver: a nanoproduct in medical application. Toxicol. Lett. 176, 1-12.

De, S.K., McMaster, M.T., Andrews, G.K., 1990. Endotoxin induction of murine metallothionein gene expression. J. Biol. Chem. 265, 15267-15274.

Geiser, W.G., Kreyling, M., 2010. Deposition and biokinetics of inhaled nanoparticles. Part. Fibre Toxicol. 7, 2

Hanus, M.J., Harris, A.T., 2013. Nanotechnology innovations for the construction industry. Prog. Mater. Sci. 58, 1056-1102.

Inoue, K., Takano, H., Kaewamatawong, T., Shimada, A., Suzuki, J., Yanagisawa, R., Tasaka, S., Ishizaka, A., Satoh, M., 2008. Role of metallothionein in lung inflammation induced by ozone exposure in mice. Free Radic. Biol. Med. 45, 1714-1722.

Ji, J.H., Jung, J.H., Kim, S.S., Yoon, J.U., Park, J.D., Choi, B.S., Chung, Y.H., Kwon, I.H., Jeong, J., Han, B.S., Shin, J.H., Sung, J.H., Song, K.S., Yu, I.J., 2007. Twenty-eight-day inhalation toxicity study of silver nanoparticles in Sprague-Dawley rats. Inhal. Toxicol. 19, 857-871.

Kaewamatawong, T., Banlunara, W., Maneewattanapinyo, P., Thammachareon, C., Ekgasit, S., 2014. Acute and subacute pulmonary toxicity caused by a single intratracheal instillation of colloidal silver nanoparticles in mice: pathobiological changes and metallothionein responses. J. Environ. Pathol. Toxicol. Oncol. 33, 59-68.

Kaiser, J.P., Roesslein, M., Diener, L., Wick, P., 2013. Human health risk of ingested nanoparticles that are added as multifunctional agents to paints: an in vitro study. PLoS One 8, e83215.

Larue, C., Castillo-Michel, H., Sobanska, S., Cecillon, L., Bureau, S., Barthes, V., Ouerdane, L., Carriere, M., Sarret, G., 2014. Foliar exposure of the crop Lactuca sativa to silver nanoparticles: evidence for internalization and changes in $\mathrm{Ag}$ speciation. J. Hazard. Mater. 264, 98-106.

Leo, B.F., Chen, S., Kyo, Y., Herpoldt, K.L., Terrill, N.J., Dunlop, I.E., McPhail, D.S., Shaffer, M.S., Schwander, S., Gow, A., Zhang, J.F., Chung, K.F., Tetley, T.D., Porter, A.E., Ryan, M.P., 2013. The stability of silver nanoparticles in a model of pulmonary surfactant. Environ. Sci. Technol. 47, 11232-11240.
Levard, C., Hotze, E.M., Lowry, G.V., Brown Jr., G.E., 2012. Environmental transformations of silver nanoparticles: impact on stability and toxicity. Environ. Sci. Technol. 46, 6900-6914.

Li, O. Mahendra, S., Lyon, D.Y., Brunet, L., Liga, M.V., Li, D., Alvarez, P.., 2008. Antimicrobial nanomaterials for water disinfection and microbial control: potential applications and implications. Water Res. 42, 4591-4602.

Liu, J., Wang, Z., Liu, F.D., Kane, A.B., Hurt, R.H., 2012. Chemical transformations of nanosilver in biological environments. ACS Nano 6, 9887-9899.

Luyts, K., Napierska, D., Nemery, B., Hoet, P.H.M., 2013. How physico-chemical characteristics of nanoparticles cause their toxicity: complex and unresolved interrelations. Environ. Sci. Process. Impacts 15, 23-38.

Mayer, M., 1999. SIMNRA, a simulation program for the analysis of NRA, RBS and ERDA. The Fifteenth International Conference on the Application of Accelerators in Research and Industry 541-544.

Namdarghanbari, M., Wobig, W., Krezoski, S., Tabatabai, N.M., Petering, D.H., 2011. Mammalian metallothionein in toxicology, cancer, and cancer chemotherapy. J. Biol. Inorg. Chem. 16, 1087-1101.

Nordberg, E.S., Arner, J., 2001. Reactive oxygen species, antioxidants, and the mammalian thioredoxin system. Free Radic. Biol. Med. 31, 1287-1312.

Smulders, S., Kaiser, J.P., Zuin, S., Van Landuyt, K.L., Golanski, L., Vanoirbeek, J., Wick, P., Hoet, P.H., 2012. Contamination of nanoparticles by endotoxin: evaluation of different test methods. Part. Fibre Toxicol. 9, 41.

Smulders, S., Luyts, K., Brabants, G., Van, L.K., Kirschhock, C., Smolders, E., Golanski, L., Vanoirbeek, J., Hoet, P.H., 2014. Toxicity of nanoparticles embedded in paints compared to pristine nanoparticles in mice. Toxicol. Sci. 141, 132-140.

Sole, V.A., Papillon, E., Cotte, M., Walter, P., Susini, J., 2007. A multiplatform code for the analysis of energy-dispersive X-ray fluorescence spectra. Spectrochim. Acta Part B-Atomic Spectrosc. 62, 63-68.

Som, C., Wick, P., Krug, H., Nowack, B., 2011. Environmental and health effects of nanomaterials in nanotextiles and facade coatings. Environ. Int. 37 (6), 1131 1142.

Stebounova, L.V., Guio, E. Grassian, V.H., 2011a. Silver nanoparticles in simulated biological media: a study of aggregation, sedimentation, and dissolution. J. Nanopart. Res. 13, 233-244.

Stebounova, L.V., Mcakova-Dodd, A., Kim, J.S., Park, H., O’Shaughnessy, P.T., Grassian, V.H., Thorne, P.S., 2011b. Nanosilver induces minimal lung toxicity or inflammation in a subacute murine inhalation model. Part. Fibre Toxicol. 8, 5.

Sung, J.H., Ji, J.H., Yoon, J.U., Kim, D.S., Song, M.Y., Jeong, J., Han, B.S., Han, J.H., Chung Y.H., Kim, J., Kim, T.S., Chang, H.K., Lee, E.J., Lee, J.H., Yu, I.J., 2008. Lung function changes in Sprague-Dawley rats after prolonged inhalation exposure to silver nanoparticles. Inhal. Toxicol. 20, 567-574.

Sung, J.H., Ji, J.H., Park, J.D., Yoon, J.U., Kim, D.S., Jeon, K.S., Song, M.Y., Jeong, J., Han, B. S., Han, J.H., Chung, Y.H., Chang, H.K., Lee, J.H., Cho, M.H., Kelman, B.J., Yu, I.J., 2009. Subchronic inhalation toxicity of silver nanoparticles. Toxicol. Sci. 108, 452-461.

Sutherland, D.E., Willans, M.J., Stillman, M.J., 2010. Supermetalation of the beta domain of human metallothionein 1a. Biochemistry 49, 3593-3601.

Takenaka, S., Karg, E., Roth, C., Schulz, H., Ziesenis, A., Heinzmann, U., Schramel, P., Heyder, J., 2001. Pulmonary and systemic distribution of inhaled ultrafine silver particles in rats. Environ. Health Perspect. 109 (Suppl. 4), 547-551.

Wijnhoven, S.W.P., Peijnenburg, W.J.G.M., Herberts, C.A., Hagens, W.I., Oomen, A.G. Heugens, E.H.W., Roszek, B., Bisschops, J., Gosens, I., Van de Meent, D., Dekkers, S., De Jong, W.H., Van Zijverden, M., Sips, A.J.A.M., Geertsma, R.E., 2009. Nanosilver-a review of available data and knowledge gaps in human and environmental risk assessment. Nanotoxicology 3, 109-138.

Yang, Z., Liu, Z.W., Allaker, R.P., Reip, P., Oxford, J., Ahmad, Z., Ren, G., 2010. A review of nanoparticle functionality and toxicity on the central nervous system. J. R Soc. Interface 7 (Suppl. 4), S411-S422.

Yu, S.J., Yin, Y.G., Liu, J.F., 2013. Silver nanoparticles in the environment. Environ. Sci. Process. Impacts 15, 78-92.

Zuin, M., Ferrari, A., Golanski, L., 2013. Leaching of nanoparticles from experimental water-borne paints under laboratory test conditions. J. Nanopart. Res. 16 